Portland State University

PDXScholar

\title{
The Archaeology of the Longue Durée: Temporal and Spatial Scale in the Evolution of Social Complexity on the Southern Northwest Coast
}

Kenneth M. Ames

Portland State University, amesk@pdx.edu

Follow this and additional works at: https://pdxscholar.library.pdx.edu/anth_fac

Part of the Archaeological Anthropology Commons

Let us know how access to this document benefits you.

\section{Citation Details}

1991 Ames, Kenneth M.,The archaeology of the longue duree: temporal and spatial scale in the evolution of social complexity on the southern Northwest Coast. Antiquity 65(249): 935-945.

This Article is brought to you for free and open access. It has been accepted for inclusion in Anthropology Faculty Publications and Presentations by an authorized administrator of PDXScholar. Please contact us if we can make this document more accessible: pdxscholar@pdx.edu. 


\title{
The archaeology of the longue durée: temporal and spatial scale in the evolution of social complexity on the southern Northwest Coast
}

\author{
KENNETH M. AMES*
}

\section{Introduction}

The emphasis on temporal and geographic scale of the French Annales school of history (cf. Braudel 1980; Baker 1984; Lewthwaite 1988) is the inspiration for this paper. Braudel (1980) divides time into three durations: short term events (days, weeks, months, a few years), medium length conjunctures (years, decades, even major portions of centuries), and longterm structures (which may last centuries, even millennia). This last duration is the longue durée. Basic to Annales' thought - and the longue durée - is the idea that to understand historical developments, to explain their causes and dynamics, one must know their temporal and their geographic scale; one must know what happened at their edges and their centre, why they developed and why they passed away; and how they changed during their span. To do this, since we cannot assume we know the scales relevant to the phenomena which interest us (Braudel 1980), we must continually play different temporal and geographic scales off against each other.

Among archaeologists, Crumley (1979) and Marquardt (1985) correctly insist that the scale of analysis affects, and determines, the patterns archaeologists detect. This thinking has parallels in chaos theory, in which phenomena that are completely patternless and disorganized at some scales display strong patterning at others.

Two aspects of scale are of interest here: the relationships between the scale of analysis and the kinds of patterns and relationships detected in the archaeological record; and the relationship between the persistence of cultural practices through time (Braun 1991) and their spatial (and demographic) scales. Madden (1983) develops the useful concept of the social interaction field that is the exchange relations in which members of a society participate. There can be many such fields, with different 'organizing principles' such as kinship, warfare and trading. The scale of a field may vary from the individual to an entire community; most will extend over large areas. Social network systems 'are the sum of the overlapping sets of social interaction fields' and are much more likely to be archaeologically observable than an individual field. An assumption of this paper is that the persistence of social practices may depend upon the spatial/and or demographic scales of the social network systems of individuals following the practice. Sedentism, for example, may require a social interaction field of a certain size to persist through time. If a group of 40 huntergatherers settles down for whatever reasons, they must still find mates, which requires an interaction field of approximately 180 to 500 people (Wobst 1974; 1976). It may be that several such fields must be sedentary at the same time for sedentism to persist in any one of them (cf. Ames 1991). Persistence of other such practices - such as social stratification - may also depend on their spatial and/or demographic scales. The consequences of evolutionary processes such as natural selection on different social practices may differ depending upon their scale. 
Crumley (1979) makes a useful distinction between homogeneous and heterogeneous regions and notes that a region that is homogeneous at one scale may be heterogeneous at another. That idea can be extended: a process may be homogeneous across a region or a time-span, and heterogeneous in its consequences. (I identify at least one such consequence below.) The obverse is also true. Different processes may be equifinal, having the same consequence, under certain conditions. Shifting analytical scales is one way to identify these situations.

Northwestern North America has an exceptional record of hunter-gatherer history spanning 11,000 years, with societies ranging from small, thinly scattered, highly mobile, midlatitude foragers during early periods to densely populous, complexly organized, fully sedentary communities in the last millennium. This archaeolngical record, in conjunction with the region's renowned ethnographic record, offers archaeologists an excellent opportunity to explore many theoretical probiems, including the effects of spatio-temporal scales on the evolution of social complexity.

Archaeologists working on the causes of social complexity on the Northwest Coast have identified demographic change, intensification of subsistence production and the evolution of storage and sedentism as crucial processes causing the complex societies of the coast. Establishing their temporal scales has always been a major research problem; their spatial scales are unknown. In western North America, as elsewhere in the world, the spatial scales of studies are frequently set by a region's research history, and even the current density of archaeologists. In North America, the culture area boundaries of Kroeber and others also set the geographic scale.

In this paper, I examine the nature of complexity on the Northwest Coast and its evolution at a much broader spatial scale than is commonly used, ignoring cultural area boundaries, for example, and using a finer temporal scale than is usual.

\section{A regional prehistory}

The southern Northwest Coast, in this paper, is the North American coast-line from the northern tip of Vancouver Island to Cape Men. decino in northern California (FIGURE 1). The compass of this paper is actually much larger, including the Fraser-Thompson and Columbia Plateaus as well. No convenient term exists for this sub-continent. McKee (1972) applied the name 'Cascadia' to an area that includes southeast Alaska, British Columbia, Washington, Oregon, Northern California, Idaho and western Montana. I will call the entire area I am discussing here 'Southern Cascadia'.

This region has an 11,000-12,000-year archaeological sequence which is usually divided into two or three periods. I divide it into the PaleoIndian (>11,000 b.p.), Archaic (11,000-5500 b.p.), Pacific (5500-270 b.p.) (following Chartkoff \& Chartkoff (1984)) and Modern (270 b.p.-present) periods, and further sub-divide the Pacific into Early (5500-3500/ 3000 b.p.), Middle (3500/3000-1500 b.p.) and Late (1500-250 h.p.). These divisions, though obscuring some of the changes I wish to highlight, are necessary for this brief summary. In this paper I only discuss the Pacific Period.

Cultural changes along the western edge of North America during the Pacific period were in parallel and very likely had the same ultimate causes. These changes include:

1 The evolution of semi- to fully sedentary settlement patterns;

2 Increasingly heavy reliance on storage;

3 Complex household-based subsistence economies;

4 Exploitation of a wide range of resources, but focusing on relatively few;

5 Manipulating the environment to eventually produce what Yen (1989) has called a 'domesticated environment';

6 Complex. specialized technologies;

7 High population densities and sometimes large communities;

8 Increasing social complexity in the form of vertical hierarchies and horizontal differentiation, including craft specialization and ethnically diverse sociocultural landscapes.

Complexity and the ethnographic record The problem of the origins of social complexity on the Northwest Coast is also a problem in the history of social complexity on the Northwest Coast; were the forms of complexity observed in the 19th century an 'event', a 'conjuncture' or a structure - did they result from the interplay between pre-contact social forms and the con- 
tact environment, or had they already existed for some time? The consensus among Northwest Coast archaeologists is that Northwest Coast culture was fully developed and stable at least by 1500 b.p., if not much earlier.

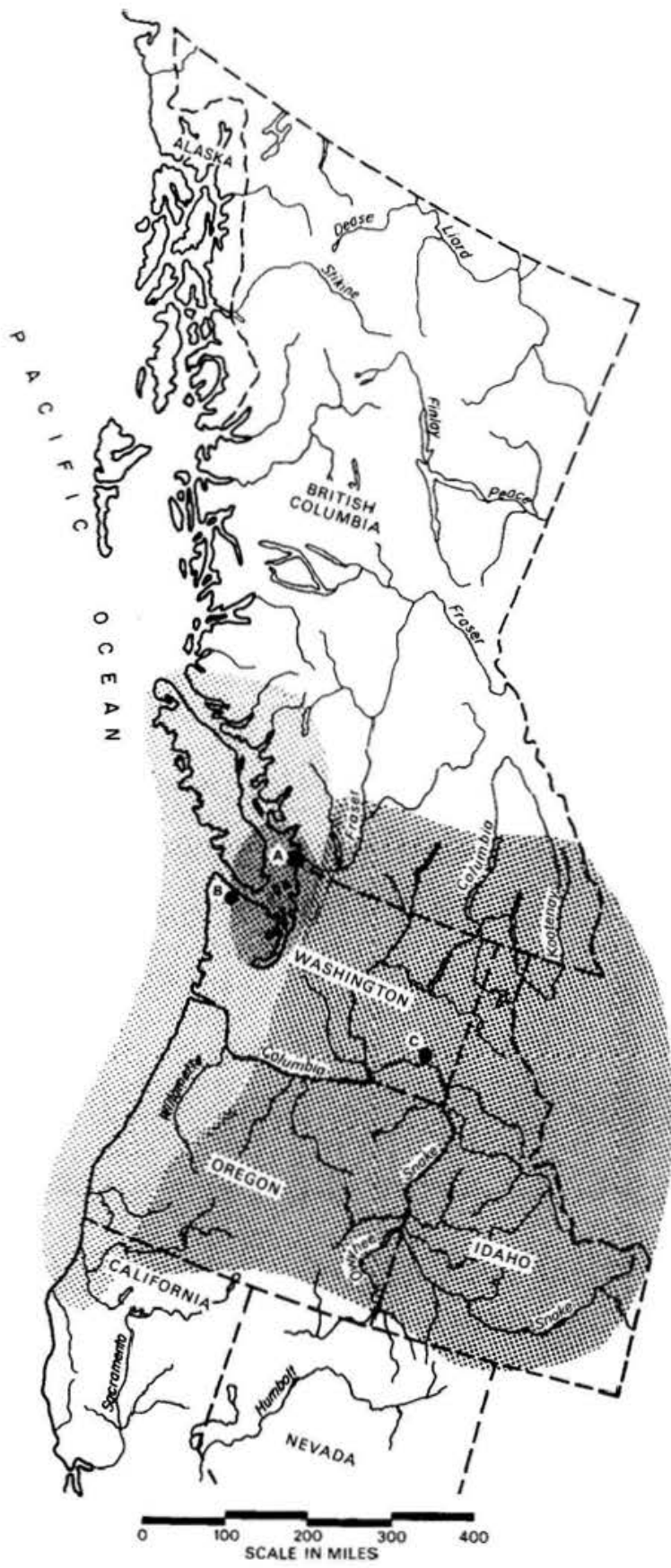

Our present understanding of Northwest Coast social complexity is based upon the vast ethnographic record of the 19th and early 20th centuries. All theoretical issues in Northwest Coast archaeology, and indirectly in the archaeology of complex hunter-gatherers (e.g. Hayden 1990), are deeply affected by this record that sets the research agenda and is the measure of all explanation. Use of the ethnographic record on the coast extends beyond simple analogy and unavoidably permeates all aspects of archaeological research.

The ethnographic texts enjoy a privileged position as a source of data and explanations relative to the archaeological record. Inconsistencies between the two are usually decided in favour of the texts. Their very scope forces investigators to work using a model of the 'typical' Northwest Coast society, masking potential temporal and spatial diversity. Most investigators acknowledge social, cultural and economic variation along the coast, but investigate it using a normative (Cordell \& Plog 1979) model of Northwest Coast culture.

The record's wealth can lead archaeologists into a naïve historicism in which the record is read farther and farther into the past. But the ethnographic pattern on the southern Northwest Coast was the result of 3000 years of sustained rapid population growth (Maschner \& Ames n.d., see below) and then sudden catastrophic depopulation coupled with equally swift culture change. Populations along the southern Northwest Coast had already experienced smallpox when the first recorded European expeditions entered the area, and in some areas were virtually extinct by the middle of the 19th centuries.

Had depopulation not occurred, had European contact been entirely benign, the

FIGURE 1. Map of Cascadia showing regions and sites mentioned in the text.

A Glenrose Cannery

B Hoko River Rockshelter

C Marmes Rockshelter.

Stippled area is the approximate extent of Southern Cascadia; lightest stipple is the southern Northwest Coast as discussed here; intermediate stipple is the Gulf of Georgia-Puget Sound region; darkest stipple is the interior, including the Columbia Plateau in the USA and southern FraserThompson Plateau in Canada. 
scope of population growth during the previous three millennia still makes the direct relevance of the ethnographic record to periods even as recent as a millennium ago an important question. If Northwest Coast culture, including social organization, subsistence etc. remained stable during that time, then we must understand how it was able to absorb such sustained growth with no appreciable organizational change. Documenting how these societies adjusted - or not - to rapid population growth and explaining that growth - becomes a major research problem. The rest of this paper suggests that social and economic change has indeed been continuous over the past two millennia.

Pacific period population dynamics

Maschner \& Ames (n.d.) have constructed separate population growth curves for the northern and southern portions of the Northwest Coast over the past 8000 years, based on radiocarbon date frequencies. The methodology and results are presented and defended elsewhere (Maschner \& Ames n.d.). Taken at the most conservative and robust level of interpretation, the curves show that while both areas experi- enced marked population growth after $\mathbf{5 5 0 0}$ b.p., their population histories differ in important detail.The curves also suggest the possibility of important fluctuations in population levels during the Pacific period.

There are two basic curves which can be extrapolated from the southern Northwest Coast data: a smooth, exponential curve (the curve on FIGURE 1) and a curve (the tops of the bars in FIGURE 2) marked by fluctuations, particularly after 1500 b.p.. Either curve suggests on-going stress on the infrastructure of southern Northwest Coast societies during most of the Pacific period. A similar model for population change in eastern Southern Cascadia also shows rapid population after 3000 b.p. and marked fluctuations after 1500 b.p. (Ames 1991). The basic pattern of population growth held throughout Southern Cascadia though the timing of certain developments may have been different.

\section{Sedentism and mobility strategies}

The development of partial to full sedentism and logistical mobility (Binford 1980) are widely seen as significant processes in the development of social complexity. The devel-

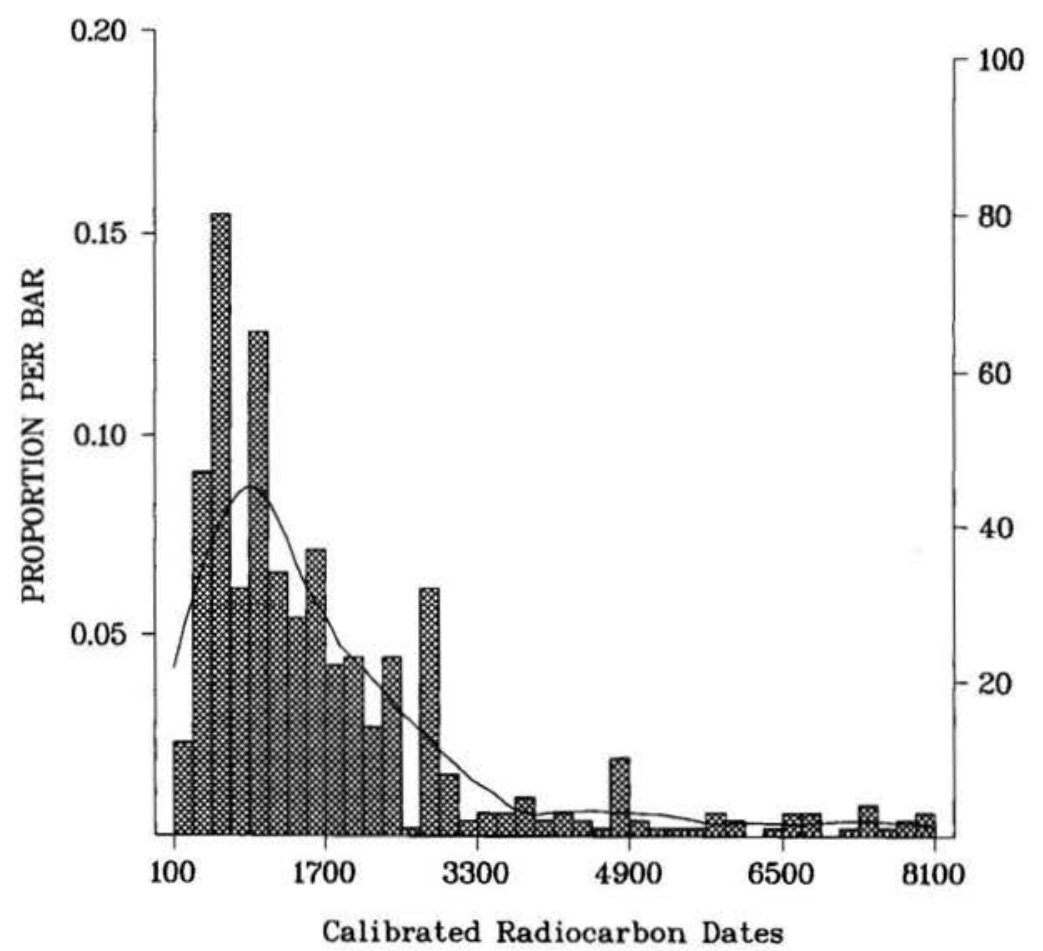

Figure 2. Population curves for Southern Cascadia. 
opment of sedentism is almost universally treated as a local event arising from local conditions (the geographic equivalent of an event). The assumption here is that a stable pattern of sedentism develops when regional structures - social network systems - emerge which are capable of sustaining sedentism. The archaeological record for southern Cascadia (and western North America) indicates that it was a development of enormous geographic extent.

Semi-subterranean pithouses dating to $c$. 5500 b.p. are the earliest domestic structures in the interior of Southern Cascadia. It is likely that house construction was sporadic until 4500 b.p. or so, when semi- to full sedentism developed (Ames 1991). That development was short lived. It has not until after 3400 b.p., that semi- to full sedentism became a permanent fixture of the cultural landscape of interior Southern Cascadia (Ames 1991).

Semi-subterranean dwellings dating to $c$. 4000 b.p. are also the earliest structures on the southern Coast (LeClair 1976; Calvert 1970; Matson 1990). On the coast, semi- to full sedentism may not have become a fixed feature of the socio-cultural landscape until after 3500 b.p. as well. Coastal sedentism was associated with large, rectangular plank houses. Plank houses appear in the archaeological record of the coast (from northern British Columbia to northern Oregon) between 3200 and 2600 b.p. (Coupland 1985; Connelly in press; Ames n.d.).

The earliest plank houses were not generally as large (Ames 1988; Coupland 1985) or as substantial as those of the late prehistoric (Mauger 1978; Ames et al. in press) and historic periods. On the other hand, they may have stood for as long a time (Ames n.d.; Ames et al. in press). Individual plank houses were sometimes used and maintained for several hundred years, representing an enormous labour investment (Ames n.d.; Ames et al. in press; Connelly in press). The appearance of plank-houses on the coast represents a long-term, multigenerational investment in a locality and has significant implications for the nature of the social order (e.g. Gilman 1981; Bender 1989).

Very large, semi-subterranean dwellings appear in the Late Pacific period in the Southern Cascadia interior. Middle Pacific pit houses were usually about $6 \mathrm{~m}$ in diameter; the later ones were as large as $18-20 \mathrm{~m}$ in diameter
(Ames 1991). Longhouses - a new house form were present by 1600 b.p. and were the dominant house form after 1000 b.p. Longhouses, made of a pole frame covered by bark mats or thatching, were sometimes more than $60 \mathrm{~m}$. long, and housed several hundred people (Rice 1985; Ames 1988).

In the 18th century $\mathrm{AD}$, plank houses of extraordinary size existed on the southern coast. These structures were $120-300 \mathrm{~m}$ long and sometimes well over $30 \mathrm{~m}$ wide. They housed large domestic groups and were a significant labour investment over their use lives (Ames et al. in press). They may indicate a domestic economy throughout the region increasingly dependent upon very complex task organization (Wilk \& Rathje 1982). These enormous households were a major economic and social innovation throughout Southern Cascadia during the Late Pacific.

If the chronology of large plank houses parallels that of longhouses, then we are seeing a regional trend in changing domestic organization within the structure of sedentism.

The ethnography-based picture of Late Pacific mobility patterns has people spending the winters in villages, and either dispersing to seasonal camps for the rest of the year or moving whole villages to fixed summer locales - classic collectors (Binford 1980). However, LatePacific-period population densities in some coastal locales may have been so high that these seasonal moves were impossible (Haggerty \& Inglis 1984; Saleeby 1983); these groups were fully sedentary, intensively exploiting a small, circumscribed territory. They were not on the forager-collector continuum. Subsequent depopulation would have permitted the seasonal mobility recorded in the ethnographic and ethnohistoric records in those areas.

\section{Specialization and regional dynamics}

Archaeological research on the southern Northwest Coast has focused on explaining the development of stratification. However, there are other aspects of complexity, ranging from individual craft and/or production specialists (e.g. Watanabe 1983) to regional specialization in production and trade in processed foods (Anastasio 1972; Hajda 1987). The issue of scale is therefore central to this topic.

It is almost impossible to chart the development of individual craft or occupational 
specialization. On the coast, production of the famous art may indicate the existence of specialists. One of the earliest pieces of art on the coast is a slotted, anthropomorphic handle from the Glenrose Cannery site in the Gulf of Georgia region dating between 4200 b.p. and 3200 b.p. The handle is thought to be that of a carving tool (Borden 1983). In the same region, Carlson (1991) recovered four well-made zoomorphic antler spoons dating between 3700 and 3000 b.p. that clearly exhibit elements of the Northwest Coast style. It is well documented then that the classic Northwest Coast art style was fully developed by 3000-2500 b.p. (e.g. Fladmark et al. 1987, MacMillan \& Nelson 1989), if not several centuries earlier.

Well-made pieces of art mobilier occur archaeologically during the last 4000 years, but it is difficult to quantify the volume or amount of art produced during that period ( $c f$. papers in Carlson 1983). There is a sense among regional archaeologists that less art was produced on the southern Northwest Coast after 1500 b.p., but that may represent a shift to media that preserve less well (Mitchell 1971), or to different contexts of disposal. In any case, the skills have been in use for a long time; we do not know the context of production.

Chatters (1986) reports a marine-shell adze blade from a house floor dating to c. 4000 b.p. on the Columbia Plateau - indicating a possible trade in tools at that early date. Making molluscshell blades requires specialized knowledge and techniques. Chatters (1989) also demonstrates the possible presence of a sea-mammal hunting specialist in a 1600-year-old plank house in the Seattle area. (Such specialists were important in the household economy during the 19th century.) Huelsbeck (1988) argues for specialized production of whale bone for trade by the Makah of Washington State during the late prehistoric period. Whale bone may have been traded prehistorically in northern British Columbia, as well (Ames n.d.).

Regional patterns of production and exchange are not easily documented, but largescale network systems clearly existed (Suttles 1990; Ames in press). Regional patterns in art styles, cranial deformation, labret wear and tattooing indicate the existence of several social network systems on the Northwest Coast (Suttles 1990). The spatial distribution of these styles, and the relations among them seems have changed over the last 3500 years (Keddie 1981; Ames in press), though it is presently not possible to chart those changes in any detail.

In the 19th century, at least, parts of Southern Cascadia specialized in the production, processing and exchange of food stuffs with others parts of the region, and perhaps areas outside the region (Anastasio 1972; Hajda 1987). Exchanges of goods for certain foods is well documented on the coast. These spheres of exchange were quite vast.

The complementary distributions of ground stone and whale bone zoomorphic and anthropomorphic clubs along the western North American coastline during the Middle and Late Pacific periods may indicate particularly farflung interaction fields. A very distinctive ground stone zoomorphic club (FIGURE 3a) is found along the California and Oregon coasts, and the lower 200 miles of the Columbia River. Whale bone clubs (FIGURES $3 \mathrm{~b}, 3 \mathrm{c}$ ) are found throughout Cascadia. Within that area, there are regional styles of whalebone clubs (Ames in press). The distributions of whale bone and stone clubs overlap along the Oregon Coast and the Lower Columbia River.

Long-distance trade in obsidian and other objects has been documented by Carlson (1983) and others. The earliest trade goods are associated with funerary ritual at the Marmes Rockshelter in eastern Washington State and just barely post-date 10,800 b.p. Exotic trade goods continued to play a rôle in funerary ritual in interior southern Cascadia at least until 45004000 b.p. (Green et al. 1986; Pavesic 1985), and well after that on the coast.

In contrast with the Northwest Coast, there is no strong evidence of regionalization of the interior Columbia Plateau during the last 5000 years or more. This may reflect the record itself, or may be an artefact of archaeological methods. But Anastasio (1972) argues that the Columbia Plateau was a single social network (unlike the coast): the material record may indicate that network is of considerable antiquity.

In sum, the archaeological and ethnographic records of Southern Cascadia clearly show that regional social networks have existed for several millennia, and that regional affiliation was an important attribute of personhood (Ames in press; Suttles 1990). The production and exchange of processed foods may have been an significant aspect of these networks. The size 

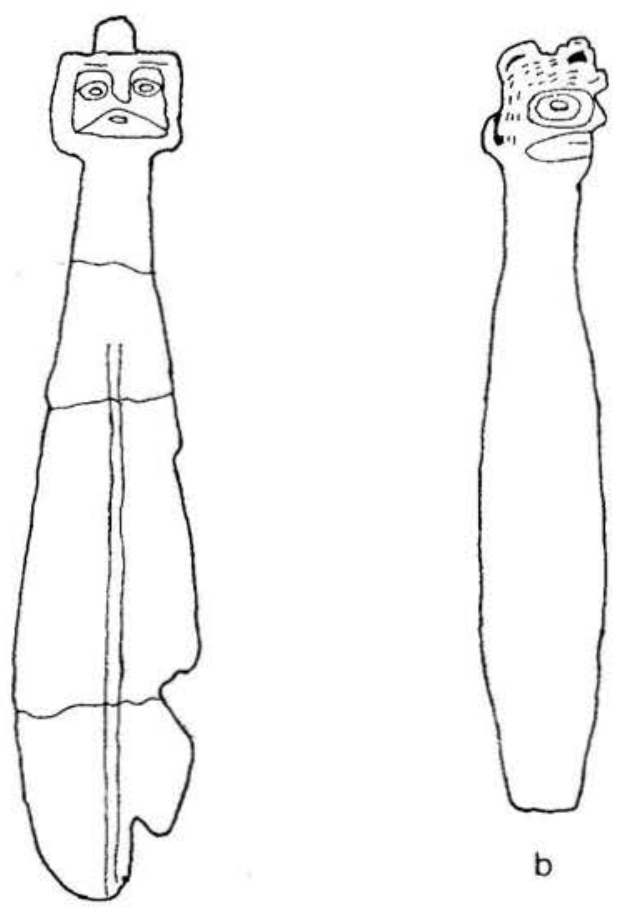

a

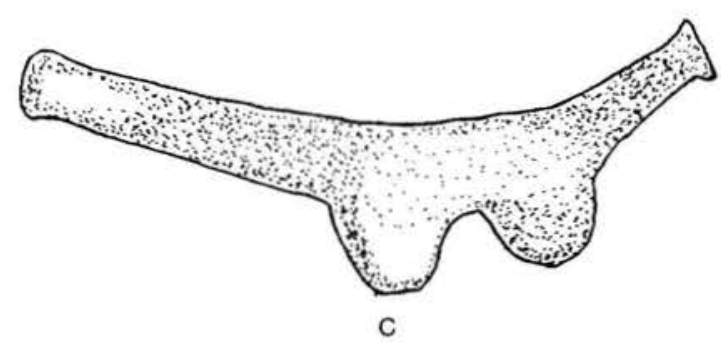

Figure 3. Clubs from Cascadia.

a, b are whale bone clubs from the Northwest Coast

c is a ground stone club of a style found from Oregon to California.

and boundaries of networks also may have changed through time. It is possible that specialized production of food and crafts by individuals is quite ancient.

\section{Intensification}

Intensification of production in southern Cascadia is an example of homogeneous evolutionary processes across a broad region producing locally heterogeneous effects. Regional prehistorians have focused on the development of heavy reliance on salmon - particularly in the form of stores - as a key element in the development of complexity on the coast. Monks (1987: 119) calls this 'salmonopia' - 'the inability to see all the food resources because of salmon'. Monks argues that many other resources produced storable surpluses (see also Croes \& Hackenberger 1988) and were crucial when salmon runs failed or stocks of dried salmon ran out or rotted (Panowski 1985). Both the archaeological and ethnographic records show that the region's subsistence economies used hundreds of species of plants, molluscs, fish and mammals. It is equally clear that within this tremendous diversity, certain resources like salmon played a central rôle. But production had to be organized to acquire and process all of these resources.

Salmonopia also blinds prehistorians to the fact that the course of intensification varied considerably from place to place, even where the same resources, techniques and equipment were used. In the interior portions of Southern Cascadia, intensification of food production proceeded along different paths in different areas; in some it led to diversification of the resource base, in others to a progressively narrower base (Atwell 1989). The actual course of intensification in a particular area cannot currently be predicted on the basis of the record for other parts of the same region. The initial resources intensified was a simple result of resource availability (Thoms 1989) though it does appear that, in the interior, significant intensification of fisheries did not occur until after 3000 b.p. and perhaps even later (Johnson 1987; Thomison 1987). From this it follows that while we can expect heavy early reliance on salmon during the Early Pacific in some areas, we cannot expect it everywhere.

The goals of intensified production also affect the spatial and temporal patterns of intensification. Food production will emphasize different mixes of resources, depending upon whether the goal of production was to maintain a secure food supply or to support seasonal aggregations (Croes \& Hackenberger 1988). Salmon became important only in the second case.

While the particular mix of resources and even the direction of intensification may have been local, intensification itself was, like sedentism, a regional phenomenon. The earliest evidence of efforts to increase production are from 
the extreme northwest and southwest corners of Cascadia - a shell midden in Southeast Alaska, and root ovens in southwest Oregon dating to about 8000 b.p. Evidence pointing to increasing food production is widespread throughout Cascadia, and California, by $5000-4000$ b.p..

Storage was a key element in changing production during the Pacific period. The earliest direct evidence for widespread storage on the Columbia Plateau post-dates 3400 h.p. (Chatters 1986). Demonstrating the presence of storage on the coast is difficult, but the appearance of rectangular, above-ground permanent structures - plank houses - may be indirect evidence of increasing reliance on storage on the coast (Ames 1988).

Though there has been little research on intensification for the period of the past 1500 2000 years (people have tended to look to the ethnographic record to reconstruct Late Pacific subsistence) there are some indicators of the consequences of Middle and Late Pacific period intensification. One of these is manipulation of the environment to create a 'domesticated environment' (Yen 1989), one that is modified and manipulated to meet subsistence economic, social and ideological needs (Cronon 1983; Merchant 1989). Widespread hurning in interior and perhaps some coastal areas (Boyd 1986) did occur. Some researchers have claimed manipulation of plant species including red cedar (Thuja plicata), camas (Camasia quamash), springbank clover (Trifolium wormskioldii), and Pacific silverweed (Potentilla anserina) (Blukis Onat in press (a); Turner \& Kuhnlein 1982; 1983), as well as the salmon stocks themselves (Blukis Onat in press (a)). It is at present impossible to document the extent of sucb practices (besides burning), or to establish when and where they began, but they can have significant effects on hunter-gatherer production and on the environment (e.g. Shipek 1989).

In the Gulf of Georgia-Northern Puget Sound area of the coast, the beginning of the Late Pacific period was marked by the widespread replacement of chipped stone by adoption of a worked bone technology, probably indicating a shift to a heavier reliance on compound tools and a more complexly organized technology as an adjustment to time stress in snbsistence pursuits (Torrence 1983). Croes \& Hackenherger (1988) see this shift as indicating increased use of salmon trolling and jigging equipment. In the same region there is evidence of an expanded spring fishery after 2500 b.p. (Ham 1983) and construction of herring traps about that time (Monks 1987). Monks argues that these traps were a way to manipulate the local trophic structure to make it more accessible to human exploitation - an aspect of a domesticated environment. Easton (1985) documents the development of reef netting - a particularly productive method of netting salmon - in the Gulf of Georgia perhaps no earlier than 500 years ago.

At the Hoko Rockshelter there is evidence of at least periodic over-exploitation of shellfish beds and fluctuating levels of shellfish usage, an increasing emphasis on salmon-fishing and a gradually expanding resource base between 900 and 100 b.p. Croes \& Hackenberger (1988) predict that shellfish werc a population limiter and that shellfish exploitation will be sensitive to human population growth. These results support their predictions.

\section{Summary and conclusions}

It is clear that the spatial scale of analysis affects the homogeneity and heterogeneity of the patterns we observe in the archaeological record. Populations on the Northwest Coast - in aggregate - grew rapidly during the past $3000-$ 4000 years. Sedentism (aod/or semi-sedentism) was the only form of residential mobility after 3500-3000 b.p. Specialized production and exchange of crafts may have begun as early as 4000 b.p., but was certainly widespread by 2500 b.p. Art and artefact style mark vast regional interaction networks. Intensification of production may have begun along the coast at least by 8000 b.p., but appear to also been widespread by $5000-4000$ b.p. through Southern Cascadia.

If we look closer, this homogeneity breaks down, and becomes unpredictable. Taking sedentism and house form as one example, the first houses everywhere appear to be pit houses. By 3000 b.p., plank houses were the norm along the entire Northwest Coast; pit houses persisted in the interior. Cross-cutting that cleavage, very large houses develop after 2000-1500 b.p. in the southern interior and probably the south coast, but not, apparently, on the northern Northwest Coast. The dynamics affecting house form and household size were not operating in parallel; the former having a north-south axis, the latter an east-west axis. The regional patterns in 
household size do seem to parallel the patterns for population growth (Ames 1991; Maschner \& Ames n.d.). Some of these developments (house form) run parallel with cuiture areas, the traditional research areas of North America, and others, big households for example, have no relationship with these traditional boundaries. Temporally, change appears to be almost continuous when viewed across 5000 years, or even, as in the case of subsistence intensification, within the last 1500 years. But these changes are not directional, as I have shown for residential patterns on the Columbia Plateau (Ames 1991). nor are developments necessarily permanent once they occur.

Northwest Coast art is clearly a structure of the longue durée; objects displaying motifs in the style appear in the record between 4200 and 3000 b.p. It does not follow from this, in my view (and contra Carlson 1991), that all other aspects of historic Northwest Coast culture developed in tandem with the art: plank houses, for example, do not appear in the record until 3200 b.p.

This historical dynamism is not unique to western North America, nor to huntergatherers. Scale and duration are as crucial to understanding any hunter-gatherers as they are to undertanding any civilization. Huntergatherers have commonly been treated as 'people without history' because their societies are determined by local wecological conditions (cf. Bettinger 1991). That is patently false.

\section{References}

AMFS, K.M. 1988. Storage, labor and sedentism in the interior Pacific Northwest. Paper presented to the 53rd annual meetings of the Society for American Archaeology, Phoenix (AZ).

1991. Sedentism, a temporal shift or a transitional change in hunter-gatherer mobility strategies, in Gregg (ed.): 109-134.

In press. Art and regional interaction among affluent foragers on the North Pacific Rim, in Blukis Onat (ed.)

n.d. The archaeology of Prince Rupert Harbor, British Columbia: the North Coast Prehistory Project excavations, 1968-1972. MS in possession of the author.

AMES, K.M., D.F. RaEtZ, S. Hamilton \& C. MCAfEe. In press. Household archaeology of a southern Northwest Coast plank house, Joornal of Field Archaeology.
The Northwest's ethnographic record must be seen for what it is, a slice through a history many millennia long. This not an argument to abandon the ethnographic record - that would be impossible and foolish. Kather, the ethnographic record should be seen as the result of a dynamic, even tumultuous history, and its direct application to the past requires continual testing (Ford 1989); and it should not be privileged as a source of insights into the past.

Social complexity and stratification on the coast has a history; it is possible that it developed more than once in time and in space; it is also likely that complexity took on different guises on the coast and in the interior, sometimes through reorganizing the same social and cultural elements. Some incarnations of complexity may not have included stratification at all, but still exhibited a complex division of labour, specialized production and intricate patterns of regional interaction (Ames in press). To be able to explain the development of social complexity on the Northwest Coast is to be able to write the history of its changes in time and space.

Acknowledgements. I would like to thank Herb Maschner and Brian Fagan for the invitation to write this paper. Jane Melville Ames read it several times, subjecting it to a penetrating stylistic critique, and measurably improving the paper's clarity and argumentation. 1 atn responsible for any errors.

ANASTASIO, A. 1972. The Southern Plateau: an ecological analysis of inter-group relations, Northwest Anthropologicol Pesearch Notes 6: 109-229.

ATwE1.1., R.G. 1989. Subsistence variability on the Columbia Plateau. M.A. Thesis, Portland State University, Portland (OR).

BAllEY, G. (ed.) 1983. Hunter-gatherer economy in prehistory. Cambridge: Cambridge University Press.

BAKER, A.R.II. 1984. Reflections on the relations of Historical Geography and the Annales school of History, in A.R.H. Baker \& D. Gregory (ed.), Explorations in Historical Geography: 1-27. Cambridge: Cambridge University Press.

Benuer, B. 1989. The roots of inequality, in D. Miller, M. Rowlands \& C. Tilley (ed.), Domination and resistonce: 83-92. London: Unwin Hyman.

BETTINGER, R.L. 1991. Hunter-gatherers: archaeologi- 
cal and evolutionary theory. New York (NY): Plenum.

BINFORD, L.R. 1980. Willow smoke and dogs' tails: hunter-gatherer settlement systems and archaeological site formation, American Antiquity 45(1): 4-20.

BLUKIS ONAT, A.R. In press (a). Cultural control of resources in the Pacific Northwest of North America, in Blukis Onat (ed.).

In press (b). (ed.). Development of HuntingGathering-Fishing Maritime Societies on the Pucific. Pullman (WA): Washington State University Press.

BORDEN, C.C. 1983. Prehistoric art in the lower Fraser region, in R.L. Carlson (ed.), Indian art traditions of the Northwest Coast: 131-66. Burnaby: Simon Fraser University Press.

BOYD, R.T. 1986. Strategies of Indian burning in the the Willamette Valley, Canadian Journal of Anthropology 5(1): 65-86.

Braudel, F. 1980. On history. Chicago (IL): The University of Chicago Press.

BRAUN, D.P. 1991. Are there cross-cultural regularities in tribal social practices?, in Gregg (ed.): 423-44.

Calvert, G. 1970. The St Mungo Cannery site: a preliminary report, BC Studies 6-7: 54-76.

CARLSON, R.L. 1983. Prehistory of the Northwest Coast, in R.L. Carlson (ed.), Indian art traditions of the Northwest Coast: 13-32. Burnaby: Simon Fraser University Press.

1991. The Northwest Coast before AD1600, in Proceedings of the Great Ocean Conferences 1 The North Pacific to 1600: 109-137. Portland (OR): Oregon Historical Society.

ChartKoff, J.L. \& K.K. ChartKoff. 1984. The archaeology of California. Palo Alto (CA): Stanford University Press.

ChATTERS, J.C. 1986. The Wells Reservoir archaeological project. Ellensburg (WA): Central Washington Archaeological Survey, Central Washington University. Archaeological report 86-6.

1989. The antiquity of economic differentiation within households in the Puget Sound region, Northwest Coast., in S. MacEachern, D.J.W. Archer \& R.D. Garvin (ed.), Households and communities: 168-178. Calgary: Archaeological association of the University of Calgary.

CONNELLY, T.J. In press. Archaeological investigation at the Palmrose and Avenue G sites, Clatsop County, Oregon. Eugene (OR): University of Oregon. Anthropology Paper.

CORDELL, L.S. \& F. PLOG. 1979. Escaping the confines of normative thought: a reevaluation of Pueblan prehistory, American Antiquity 44: 405-29.

Coupland, G. 1985. Prehistoric culture change at Kitselas Canyon. Unpublished Ph.D dissertation, University of British Columbia, Vancouver.
Croes, D.R. \& S. HaCKenBerger. 1988. Hoko River archaeological complex: modeling prehistoric Northwest Coast economic evolution, Research in Economic Anthropology supplement 3: 19-86.

Cronon, W. 1983. Changes in the land: Indians, colonists, and the ecology of new England. New York (NY): Hill \& Wang.

CRUMLEY, C.L. 1979. Three locational models: an epistemological assessment for anthropology and archaeology, Advances in Archaeological Method and Theory 2: 141-73.

EAston, N.A. 1985. The underwater archaeology of Straits Salish reef-netting. MA thesis, University of Victoria, Victoria.

Fladmark, K.R., D.E. Nelson, T.A. BroWn, J.S. Vogel. \& J.R. SOUTHEN. 1987. AMS dating of two wooden artifacts from the Northwest Coast, Canadian Journal of Archaeology 11: 1-12.

FORD, P.J. 1989. Archaeological and ethnographic correlates of seasonality: problems and solutions on the Northwest Coast, Canadian Journal of Archaeology 13: 133-50.

GILMAN, A. 1981. The development of social stratification in Bronze Age Europe, Current Anthropology 22: 1-23.

Green,T.J., M.G. PAvesic, J.C. Woods \& G.L. Titmus. 1986. The DeMoss burial locality: preliminary observations, Idaho Archaeologist 9: 1-10.

GREGG, S.A. (ed.). 1991. Between bands and states: sedentism, subsistence and interaction in small scale societies. Carbondale (IL): Southern Illinois University Press. Occasional Paper 9.

HAGGERTY, J.C. \& R.INGLIS. 1984. Coastal site survey: theoretical implications of a new methodology. Paper presented to the 17th Annual Canadian Archaeological Association meetings, Victoria, B.C. April, 1984.

HAJDA, Y. 1987. Exchange patterns on the Greater Lower Columbia. Paper presented at the 80th Annual Meetings of the American Anthropological Society, Chicago, November 1987.

НАм, L.C. 1983. Seasonality, shell midden layers and Coast Salish subsistence activities at the Crescent Beach site, $\mathrm{DgRr}$ 1. Unpublished Ph.D dissertation, University of British Columbia, Vancouver.

Harris, D.R. \& G.C. Hilliman. (ed.). 1989. Foraging and farming: the evolution of plant exploitation. London: Unwin Hyman.

HAYDEN, B. 1990. Nimrods, piscators, pluckers, and planters: the emergence of food production, Journal of Anthropological Archaeology 9: 31-69.

HUELSBECK, D.R. 1988. The surplus economy of the Northwest Coast, Research in Economic Anthropology supplement 3: 49-77.

JOHNSON, R.T. 1987. Archaeological evidence of fishing in the southern Plateau, a culture area of the 
Columbia Plateau. M.A. thesis, University of Idaho, Moscow (ID).

KEDDIE, G.R. 1981. The use and distribution of labrets on the north Pacific rim, Syesis 4: 60-80.

LECL.AIR, R. 1976. Investigations at the Mauer site near Agassiz, in R.L. Carlson (ed.), Current Research Reports: 76-104. Burnaby: Simon Fraser University. Department of Archaeology Publication 3.

LEWTHWAITE; J. 1988. Trial by durée: a review of historical-geographical concepts relevant to the archaeology of settlement on Corsica and Sardinia, in J.L. Bintliff, D.A. Davidson \& E.G. Grant (ed.), Conceptual issues in environmental archaeology: 161-88. Edinburgh: Edinburgh University Press.

MADDEN, M. 1983.. Social network systems amongst hunter-gatherers considered within southern Norway, in Bailey (ed.): 191-200.

MARQUARDT, W.H. 1985. Complexity and scale in the study of fisher-gatherer-hunters: an example from the eastern United States, in T.D. Price \& J.A. Brown (ed.), Prehistoric Hunter-Gatherers: the emergence of complexity: 59-99. Orlando (FL): Academic Press.

MASCHNeR, H.D.G. \& K.M. Ames. n.d. Prehistoric population dynamics on the Northwest Coast of North America. MS in possession of the authors.

MATSON, R.G. 1990. Households as economic organization; a comparison between Northwest Coast and Southwestern large houses. Paper presented to the 89th Annual Meeting of the American Anthropological Association, New Orleans, December, 1990.

MAuger, J.E. 1978. Shed roof houses at the Ozette archaeological site: a protohistoric architectural system. Pullman (WA): Washington State University. Washington Archaeological Research Center Project Report 73.

MCKEE, B. 1972. Cascadia: the geological evolution of the Pacific Northwest. New York (NY): McGrawHill.

MCMILLAN, A.D. \& D.E. NELSON. 1989. Visual punning and the whales' tail: AMS dating of a Marpole-age art object, Canadian Journal of Archaeology 13: 212-18.

MERCHANT, C. 1989. Ecological revolutions: nature, gender and science in New England. Chapel Hill (NC): University of North Carolina Press.

MrTCHELL, D. 1971. Archaeology of the Gulf of Georgia area: a natural region and its culture types, Syesis 4 supplement 1 .

MONKS, G.C. 1987. Prey as bait, Canadian Journal of Archaeology 11: 119-42.

PANOWSK1, E.J.T. 1985. Analyzing hunter-gatherers: population pressure, subsistence, social organization, Northwest Coast societies, and slavery. Unpublished Ph.D dissertation, University of New Mexico.
PAvesic, M.G. 1985. Cache blades and turkey tails: piecing together the Western Idaho Archaic burial complex, in M.G. Plew, J.C.Woods \& M.G. Pavesic (ed.), Stone tool analysis; essays in honor of Don E. Crabtree: 55-90. Albuquerque (NM): University of New Mexico Press.

RICE, H.S. 1985. North American dwellings and attendant structures on the Southern Plateau. Cheney (WA): Eastern Washington University. Archaeological and Historical Services, Eastern Washington University Report in Archaeology and History 100-44.

SALEEBY, B. 1983. Prehistoric settlement patterns in the Portland Basin on the Lower Columbia River: ethnohistoric, archaeological and biogeographic perspectives. Unpublished Ph.D dissertation, University of Oregon.

SHIPEK, F.C. 1989. An example of intensive plant husbandry: the Kumeyaay of Southern California, in Harris \& Hillman (ed.).

SuTtLes, W. 1990. Introduction, in W. Suttles (ed.), Handbook of North American Indians 7: Northwest Coast: 1-15. Washington (DC): Smithsonian Institution Press.

Thomison, P. 1987. When Celilo was Celilo, an anlysis of salmon use during the past 11,000 years in the Columbia Plateau. MA thesis, Oregon State University, Corvallis.

Thoms, A.V. 1989 The northern roots of huntergatherer intensification: camas and the Pacific Northwest. Unpublished Ph.D dissertation, Washington State University, Pullman (WA).

TORRENCE, R. 1983. Time budgeting in prehistory, in Bailey (ed.): 11-22.

TURNER, N. \& H. KUHNLEIN. 1982. Two important 'root' foods of the Northwest Coast Indians: Springback clover (Trifolium wormskioldii) and Pacific silverweed (Potentillam anserina spp. pacifica), Economic Botany 36: 411-32.

1983 Camas (Camassia spp.) and riceroot (Fritillaria spp.): two lilaceous 'root' foods of the Northwest Coast Indians, Ecology of Food and Nutrition 13: 199-219.

Watanabe, H. 1983. Occupational differentiation and social stratification: the case of Northern Pacific maritime food-gatherers, Current Anthropology 24: 217-19.

WILK, R.R. \& W.L. RATHJE. 1982. Household archaeology, American Behavioral Scientist 25(6): 617-40.

WOBST, H.M. 1974. Boundary conditions for Paleolithic social systems: a simulation approach, American Antiquity 39: 47-79.

1976. Locational relationships in Paleolithic society, Journal of Human Evolution 5: 49-58.

YEN, D.E.A. 1989. The domestication of the environment, in Harris \& Hillman (ed.): 55-78. 